\title{
Study on the Management Strategy of Chinese overseas students Based on the cooperation of WUST and WU
}

\author{
Liu Yong', Deng Xudong ${ }^{2}$ \\ ${ }^{1}$ School of Management, Wuhan University of Science and Technology \\ ${ }^{2}$ School of Management, Wuhan University of Science and Technology
}

\begin{abstract}
With the development of Sino-foreign cooperative education and internationalization, more and more Chinese students have been to U.S. and other countries, in order to acquire international experience, or dual degree both from domestic and foreign universities. It's a little bit difficult to know the conditions of Chinese universities, which are why the university should take good management strategies to help students better integrate into American's living and learning culture, in order to get good results. This article analyzed those students' difficulties of learning and living through questionnaire investigation, understand the situation and demand of the students, and then design the appropriate management strategies.
\end{abstract}

Keywords: Overseas students' problems, Communication channel, Management strategy

\section{Introduction}

With the development of Chinese high education internationalization, a lot of problems of cooperative management have appeared, especially management of those students who learned in the foreign countries.

Many Chinese universities have taken the new model to educate their students, such as " $\mathrm{x}+\mathrm{y}$ " project, which means studying two years in China, and another one, two or three years in America. If they can get enough credits required by the two universities, they can get dual degree.

Firstly, different from the students who directly applied for the admission from American universities, those exchange or dual degree seeking students are both belonged to two universities, and their transcript should transferred from one university to another university. So for such kind of students they faced with some common problems just like other foreign students, for example: culture confliction, learning pressure and so on; they also had different problems, such as course selection, transcript transferred both from China to US and US to China.

Secondly, as we know, American universities take the foreign students as the same to their own students, so universities can't provide special service to the foreign students, no foreign students' dormitory, library, no special guide, they want to foreign students have more chance to communicate American people, understand its culture ${ }^{[1]}$. But it also brought some difficulties to the foreign students.

Based on the exchange students or dual-degree seeking students' characteristics, and the rules of American universities to the foreign students, it is very important to take appropriate management strategy and make them adapt to the new environment.

\section{Literature Review}

Many research papers have been concerned about problems of the students studying in foreign countries because of the big number of going abroad.

\subsection{Investigation and problems summary of students going abroad}

Zhao Jian, Wu Junji (2014) ${ }^{[2]}$ indicated Chinese overseas students' recognition ability is higher than other countries overseas students, but lower behavioral ability. So Chinese overseas students always communicate with foreign students or people inactively. That is partly because most Chinese overseas students' language ability is not good enough, or lacking of knowledge of Chinese culture and foreign culture. (Zhao Jian, WU Junji (2014) ${ }^{[2]}$; Shen $\left.\mathrm{Jia}(2014)^{[3]}\right)$. Chinese overseas students mainly get support no matter in financial support or moral Consolation just from their family when they are in emergency ${ }^{[4]}$.

\subsection{Exist Strategies to the problems of Chinese overseas students}

Wang Dianjian(2013 $)^{[5]}$ analyzed overseas students culture and language problems, provided overseas students should manage and learn by themselves to adapt to foreign environment, such as better time utilization, communicate with foreigners more and so on.

Shen Jia $(2014)^{[3]}$ thought Chinese professors should teach some culture knowledge to help students get better understanding of Chinese culture. 
Fu Cheng $(2013)^{[1]}$ summarized importance of the reeducation to the returned students, he thought returned students are affected by their overseas life, and suffer "the second cross-culture adaptation", so the university would give some lecture and seminar to help returned students adapt to domestic environment.

Liu Chao el., (2014) ${ }^{[6]}$ proposed it's good to use visiting scholar to the cooperation university to help overseas students finish their study abroad. Through present study, we believed many researchers have analyzed the living and learning problems of overseas students, come up to some suggestions from the angle of country, foreign universities and individual, but lack of the strategies of both universities, or not specific enough too. This paper just focuses on the strategies that both cooperating universities should take; in order to further the cooperation and help students finish their study smoothly.

\section{Investigation of WUST's Students studied in WU}

We took our university's students who went to WU as investigation object, through questionnaire and online indepth interview, got the problems of our students, such as: cross-culture adaptation, high cost of living and learning, and so on, but still have some unique situations here.

\subsection{Language is still the big problem}

According to the investigation of our university's exchange and dual-degree seeking students, we found almost 50\% students are willing to communicate with their classmates, more than $70 \%$ want to talk to their professors, but they didn't communicate more often because they were afraid of their oral English is not good enough and cause misunderstanding. Although our students have been learned English about 10 years, even more, they're not confident in their spoken English. And most students felt they can't get all the points of the course especially in the first term in WU, although they know some concepts and professional terms.

\subsection{Culture difference gets in the way}

More like to be told some regulations and rules of WU by the adviser, instead of reading by themselves. Students always make complaint to me; they don't know they should do, nobody told them....... Actually that information has been on the website all the time. But Chinese students have been nursed too well in China. Chinese professors, advisers, parents reminded them to do everything time to time. That's why they couldn't adapt to the independent environment. Although our students have excellent scores in most courses, in some extent they don't have enough ability to live independently.

\subsection{Higher pressure of learning in WU than in WUST}

Half of our students expressed they beard bigger pressure of learning in WU. In order to get good results, they work hard and stay up late.

Not like students in China or local American students, every exchange students and dual-degree seeking students said they never cheated in any examination in WU. They are not cheating not only because the professors would withdraw their scores, but also afraid of be despised by American students.

\section{Management strategy to Students learning in WU}

\subsection{Establish dual-adviser system, intensify process management}

- Establish dual-adviser

For any students go to WU, arrange two advisers, one is adviser of WUST, the other is in WU. Before students go to the U.S., Chinese adviser should give guide on the transcript transferring, culture knowledge, course selection, and the other matters should be attention. One side to help students better integrated into American environment, the other side requires students responsible for themselves.

When students are in WU, mainly get suggestion of studying from WU's adviser, and students should report to the Chinese adviser once a month at least through email.

When students go back, the Chinese adviser is responsible for their transcript transferring to WUST.

- Carry out process management

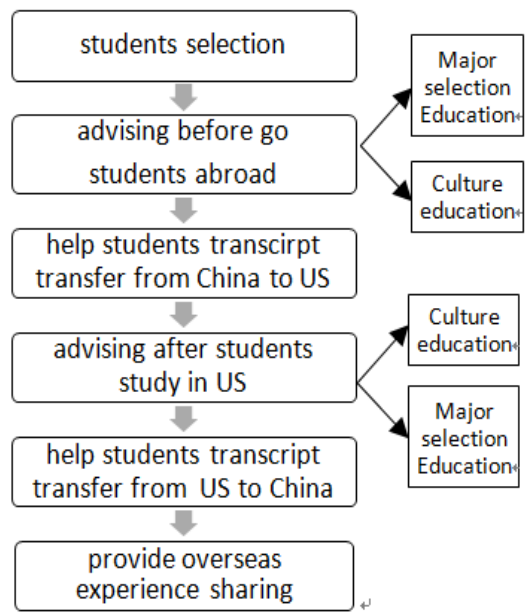

FIG 1: Process management for the student studying abroad

\subsection{Set up WU-WUST project team, use uniform management platform}

Taking the school as the team leader, personnel of academic department, international office as the team 
member; establish project team to manage those exchange students and dual-degree seeking students.

Different from former ideas, overseas students managed by the international office, we think students should be managed mainly by the school that they belong to, which can help students choose right courses, use right ways of learning, better integrated into foreign environment.

The international office and academic department can give support to the school and do some assistant job.

\subsection{Provide diversified courses to improve students' language ability}

- Open more courses taught in bilingual language According to the investigation, our students like foreign professor's teaching model more. So Chinese professors can use the English teaching materials and give the course both in English and Chinese.

- Offer the courses of culture

Due to culture difference and not having good culture knowledge, overseas students are not active enough to communicate. So the culture courses can help students to talk actively and positively.

- Set up the third language course

The more language they know not only can broaden their vision, but also can increase students confidence, it would be easier for them to communicate with other country students.

- Encourage students selecting English courses in WU.

Even not all the English courses credits can be transferred to domestic university, but it's very important and good to improve the English ability of the students, which can help them learn major courses.

\subsection{Apply multi-channels to communicate with overseas students.}

Establish QQ group, email, overseas students union, in the meanwhile arouse students take all kinds WU's campus activities, which can help them adapt to foreign environment quickly.

\section{Conclusion}

Having 10 years cooperation history with WU, we have a lot of experience of co-educating students, but still encountered some embarrassments; this paper provided some good suggestions of solving the problems we faced with, and also can be an example for other universities.

\section{Reference:}

[1] Fu Cheng, "Study on International students' assistance program from Cross cultural perspective", Continue Education Research, pp. 158-160, 2013(10)
[2]Zhao Jia, Wu Junji, "Comparing study of Sino-foreign students cross-culture communication ability", Overseas English, pp. 232-233, 2014(9)

[3] Sheng Jia, "Chinese cultural aphasia of overseas students from Intercultural communication perspective", Journal of Huaihua Univsersity, pp.111-114, 2014(10)

[4] Zhang Fandi, "Investigation of social support of Chinese students studying in the United States", Journal of Shenyang University (Social Science), pp. 278-280, 2014, (2)

[5] Wang Dianjian, "The study on the difficulties and coping strategies of Chinese students' cross-cultural academic adaptation", Journal of Lanzhou Jiaotong University, pp. 147-150, 2013 (5)

[6] Liu Chao, Xiong Ying, Xu Fangfang, "Study on the diversified management of overseas students based on the Sino-foreign cooperative education", Journal of Business Managers, pp. 255, 2014(11) 